\title{
Effect Inoculant of Trichoderma viride and Saccharomyces cerevisiae Mixed Culture on Chemical Composition, Fiber, Digestibility, and Theobromine Cocoa Pod Fermentation
}

\author{
Zakariah MA \\ Islamic College of Al Mawaddah Warrahmah \\ Jl. Pondok Pesantren No. 10, Kolaka, South East Sulawesi, Indonesia \\ m.askari.zakariah@mail.ugm.ac.id
}

\begin{abstract}
The objective of this study was to identify the effect of Trichoderma viride and Saccharomyces cerevisiae inoculant on chemical compositions, digestibility, and theobromine content of fermented cocoa pod. The experiment consisted of four treatments, namely cocoa pods without fermentation as control (R0); fermentation of cocoa pods with innoculant $T$. viride (R1); fermentation of cocoa pods with innoculant $S$. cerevisiae (R2); and fermentation of cocoa pods with innoculant $T$. viride and $S$. cerevisiae mixed culture (R3). Each treatment had three replications, cocoa pod was fermented for 10 days. Variables observed were: chemical compositions i.e. dry matter (DM), organic matter (OM), crude protein $(\mathrm{CP})$, ether extract (EE), crude fiber (CF), nitrogen free extract (NFE), fiber fraction (neutral detergent fiber and acid detergent fiber), in vitro digestibility, and theobromine content. Data were analysed by one-way analysis of variance and followed by Duncan's new multiple range test (DMRT), if there were any significant differences. Results showed the inoculum affected $(\mathrm{P}<0.05)$ the chemical composition, fiber fraction and in vitro digestibility. However, theobromine was not detected neither in cocoa pod without fermentation nor in fermentation. Compared to the control group, inoculation with $T$. viride and $S$. cerevisiae mixed culture $(\mathrm{P}<0.05)$ resulted in higher $\mathrm{DM}$ content $(92.78$ vs $89.72 \%$ respectively), higher CP (7.43 vs $5.63 \%$ respectively), higher NDF (79.41 vs $61.18 \%$ respectively), higher ADF (73.04 vs $47.94 \%$ respectively), but was not significantly different on DM and OM digestibility ( 21.22 vs $22.24 \%$ and 22.67 vs $24.31 \%$ respectively) than cocoa pod without fermentation. It is concluded that inoculant $T$. viride and $S$. cerevisiae mixed culture increased CP content, but had no effect on in vitro digestibility.
\end{abstract}

Key Words: Cocoa Pod, Fermentation, Trichoderma viride, Saccharomyces cerevisiae

\section{INTRODUTION}

Limited availability of forage, force people to seek for other alternative feeds that could replace a part or total forages. Plantation wastes to be one option in dealing with the issue of the lack of forage availability in the dry season, but waste products of plantation could also pollute the environment. According to Ditjen Perkebunan (2012), there were approximately $1,745,789$ ha of cocoa plantation in 2011 .

Cocoa pod contain various minerals. Toharmat et al. (2006), reported that feeding cocoa pod to Etawa goat as a fiber source also provide, $\mathrm{Mg}$ and $\mathrm{Zn}$ in a higher content than those provided by grass, bark coffee husk, and rice straw. Wahyuni et al. (2008) reported that fermented cocoa pod can be used as animal feed in growing goats up to the level of $40 \%$. Puastuti et al. (2008) reported that a ration based cocoa pod without ammoniation but with organic $\mathrm{Zn}$ supplementation resulted in weight gain equivalent to the daily ration of grass-based, caused by sufficient consumption rate and nutrient digestibility, $\mathrm{N}$ retention and good fermentation characteristics. Ginting (2004) reported that pod husks of more than $15 \%$ in the ration can reduce performances of goats.

Cocoa plantation wastes such as pod husks are commonly just piled up in the field after being harvested. This practice can cause discomfort odor or emerging which cause 
disease to the cocoa plants. Pod husks contained anti nutritive substances such as theobromine that limits its level of inclusion in the diets. Efforts to improve the nutritive quality of the cocoa pod including, drying, addition of urea (ammoniation), and fermentation. The objectives of this study was to investigate the effect of fermenting cocoa pod using different types of innoculant on the chemical composition, digestibility, and theobromine content.

\section{MATERIAL AND METHODS}

The experiment was performed at the Laboratory Animal Feed Technology, Laboratory Biochemistry of Nutrition, Feed Animal Nutrition Department, Faculty of Animal Science, Gadjah Mada University.

Instruments used included scales capacity $10 \mathrm{~kg}$ with sensitivity of $0.1 \mathrm{~kg}$, sealer and vacuum, grinder with sieve diameter's $1 \mathrm{~mm}$, analytic scales with sensitivity of $0.0001 \mathrm{~g}$, $\mathrm{pH}$ meter, digital thermometer, oven, lactic analysis tools, ammonia rumen tools, in vitro tools, gas chromatography tools, and high performance liquid chromatography Knauer type UV 6000 LP. Materials used included cocoa pod, inoculant of L. plantarum, inoculant of $S$. cerevisiae, cassava meal, water, chemicals for proximate analysis, ruminal fermentation, theobromine analysis, and in vitro digestibility.

\section{Substrate preparation, fermentation, and treatments}

Fresh cocoa pod was collected from traditional farming Gunung Kidul Regency. Cocoa pod was cut to size of $1 \times 5 \mathrm{~cm}$ and sun-dried for 10 hours to decrease the water content. Two species of fungal were used as innoculant, namely $T$. viride and $S$. cerevisiae.

Fermentation was conducted at laboratory scale in room that was sterile. The room was watered with desinfectan, the tools were sterealised with alcohol (90\%). Cocoa pod was fermented in fermenter bag (as silo), and inoculated with T. viride and S.cerevisiae was performed at $1 \%$ dry matter, by mixing and spreading the innoculant evenly. Silo was made to be aerobic by making a hole.The length of fermentation was set at 10 days at room temperature (Ginting \& Krisnan 2006).

Three processing treatments and one control treatment were as follows: R0: Unfermented cocoa; R1: Cocoa pod fermented using T. viride; R2: Cocoa pod fermented using S. cerevisiae; and R3: Cocoa pod fermented using T. viride and S. cerevisiae mixture.

\section{Chemical analysis}

Samples of dried silages were analyzed for chemical compositions using proximate analyses (AOAC 2005). Neutral Detergent Fiber (NDF) and Acid Detergent Fiber (ADF) analyses were performed according to the procedures of Van Soest \& Robertson (1985). In vitro digestibility study was performed according to the procedures of Tilley \& Terry (1963) at Biochemical Nutrition Laboratory, of Animal Science Faculty, the Gadjah Mada University. Theobromine analysis to was conducted as recommended by European Food Safety Authority using HPLC (AOAC 2005).

Data of chemical composition, fiber fraction, and in vitro digestibility were analyzed using analysis of variance (ANOVA) and followed by Duncan's new multiple range test (DMRT) if there were any significant differences (Steel \& Torrie 1993). All of statistic calculation was performed using software of Statistical Product and Service Solution version 16.0 (Soleh 2005). 


\section{RESULTS AND DISCUSSION}

\section{Proximate and fiber fraction composition of fermented cocoa pod}

The fermented cocoa pods have higher dry matter content than that of the unfermented cocoa pod. The Increased dry matter contents of the fermented cocoa pod might be caused by any growth of fungal in cocoa pod. The growth of fungi was characteritically slower than that of bacterial $T$. viride secreted cellulose at eight days, which can be influenced dry matter content. Suparjo et al. (2009) reported that fungi would utilized the organic matter from substrate and caused losses in dry matter. Mulato \& Widyatomo (2003) showed that time of fermentation can affect the dry matter content of substrates. The proximate compositions were shown in Table 1.

Tabel 1. Chemical composition of unfermented cocoa pod (R0), fermented cocoa pod with $T$. Viride (R1), S. cerevisiae (R2), T. Viride and S. cerevisiae mixed culture (R3) inoculant

\begin{tabular}{lcccccc}
\hline \hline Treatment & DM & OM & CP & EE & CF & NFE \\
\hline R0 & $89.72^{\mathrm{a}}$ & 90.55 & $5.63^{\mathrm{a}}$ & 1.71 & $31.08^{\mathrm{a}}$ & $51.93^{\mathrm{d}}$ \\
R1 & $91.94^{\mathrm{b}}$ & 85.30 & $9.57^{\mathrm{b}}$ & 2.41 & $35.99^{\mathrm{c}}$ & $37.11^{\mathrm{b}}$ \\
R2 & $92.70^{\mathrm{b}}$ & 84.07 & $8.50^{\mathrm{c}}$ & 2.43 & $31.83^{\mathrm{b}}$ & $41.12^{\mathrm{c}}$ \\
R3 & $92.78^{\mathrm{b}}$ & 84.09 & $7.43^{\mathrm{d}}$ & 2.44 & $40.03^{\mathrm{d}}$ & $34.00^{\mathrm{a}}$ \\
\hline
\end{tabular}

a,b,c Different supercripts at the same column indicate significant difference $(\mathrm{P}<0.05)$

Crude protein content was significantly affected by the type of innoculants. Inoculation with $T$. viride had highest effect on crude protein level. Ginting \& Krisnan (2006), showed that fermentation using Trichoderma sp. as an innoculant increased the crude protein content of the substrates. In the current experiment the crude protein content was lower when treated with $T$. viride and $S$. cerevisiae mixed culture, which could be due to any negative interactions between both of innoculant.

Fungal innoculation significantly increased crude fiber contents of the fermented cocoa pods. This higher crude fiber content could be caused by increased cell wall, of the hyfa of fungal. Utomo (2001), reported that crude fiber is organic matter which was divided to celulosa, hemicellulosa, and lignin. All of these components were found in hyfa of fungi. Cocoa pods fermentation with $T$. viride and $S$. cerevisiae mixed culture have higher free extract nitrogen content. During the stationary phase, the $T$. viride used the substrate free extract nitrogen before degrading the cellulose. Kamara et al. (2008) showed that glucose at early phase was used by $T$. viride for growing and then strated to degrade of fiber. The fiber fractions of substrates were presented in Table 2.

Neutral detergent fiber and ADF content were significantly higher in the fermented cocoa pod compared to the unfermented ones. Fungi types affected the NDF and ADF content of fermented cocoa pod. Cell wall increased during the prolonged time of fermentation. This result differed to that reported by Alemawor et al. (2009), who reported that cocoa pods fermented with Aspergillus niger have lower cell wall contents.

\section{In vitro digestibility of cocoa pod fermentation}

The effects of fermentation and type of inoculants on the in vitro digestibility were showed in Table 3. In vitro digestibility of substrate dry matter and organic matter was significantly affected by fermentation. Unfermented cocoa pod have higher DM and OM digestibility than those fermented with $T$. viride, but were not significantly different to than 
those of fermented cocoa pods using inoculant of $T$. viride and $S$. cerevisiae mixed culture. Utomo (2001), reported that ADF is hardly to be degraded so that it could become an inhibitor in feed. Yunus (1997) reported that factors that affect the in vitro digestibility are composition of feed, ruminal fluid temperature, time of incubation and analysis method.

Table 2. Fiber fraction content of fermented and unfermented cocoa pod

\begin{tabular}{lcc}
\hline \hline Treatment & Neutral detergent fiber & Acid detergent fiber \\
\hline R0 & $61.18^{\mathrm{a}}$ & $47.94^{\mathrm{a}}$ \\
R1 & $74.66^{\mathrm{b}}$ & $67.32^{\mathrm{b}}$ \\
R2 & $79.36^{\mathrm{c}}$ & $73.93^{\mathrm{c}}$ \\
R3 & $79.41^{\mathrm{c}}$ & $73.04^{\mathrm{c}}$ \\
\hline
\end{tabular}

${ }_{a, b, c}$ Different supercripts at the same column indicate significant difference $(\mathrm{P}<0.05)$; R0: Unfermented cocoa pod; R1: Fermented cocoa pod were inoculated $T$. viride; R2: Inoculated $S$. cerevisiae; R3: Inoculated $T$. viride and $S$. cerevisiae mixed culture

Table 3. In vitro digestibility of fermented and unfermented cocoa pod

\begin{tabular}{lcc}
\hline \hline Treatment & DM digestibility $(\%)$ & OM digestibility $(\%)$ \\
\hline R0 & $22.24^{\mathrm{b}}$ & $24.31^{\mathrm{b}}$ \\
R1 & $10.69^{\mathrm{a}}$ & $12.60^{\mathrm{a}}$ \\
R2 & $11.72^{\mathrm{a}}$ & $13.57^{\mathrm{a}}$ \\
R3 & $21.23^{\mathrm{ab}}$ & $22.68^{\mathrm{ab}}$ \\
\hline
\end{tabular}

${ }^{a, b, c}$ Different supercripts at the same column indicate significant difference $(\mathrm{P}<0.05)$; R0: Unfermented cocoa pod; R1: Fermented cocoa pod were inoculated T. viride; R2: Inoculated $S$. cerevisiae; R3: Inoculated $T$. viride and $S$. cerevisiae mixed culture

The theobromine content of fermented and unfermented cocoa pods presented in Table 4. Theobromine content of unfermented and fermented cocoa pods were not detected by HPLC. This was caused by the pre-preparation procedures including sun dried for 10 hours, this porocess might have reduced theobromine content. Mulato \& Widyatomo (2003), showed that dried and boiled can decrease theobromine content.

Table 4. Theobromine content of fermented and unfermented cocoa pod

\begin{tabular}{lc}
\hline \hline Treatment & Theobromine content (ppm) \\
\hline R0 & $<0.03$ \\
R1 & $<0.03$ \\
R2 & $<0.03$ \\
R3 & $<0.03$ \\
\hline
\end{tabular}

R0: Unfermented cocoa pod; R1: Fermented cocoa pod were inoculated T. viride; R2: Inoculated $S$. cerevisiae; R3: Inoculated $T$. viride and $S$. cerevisiae mixed culture

\section{CONCLUSION}

It is concluded that inoculation with $T$. viride and $S$. cerevisiae mixed cultures in fermenting cocoa pods affected the chemical composition and fiber fraction. However it did not affect the in vitro DM and OM digestibility of cocoa pod. The theobromine content of the fermented and unfermented was not detected in this study. 


\section{REFERENCES}

Alemawor F, Dzogbefia VP, Oddoye EOK, Oldham JH. 2009. Enzyme cocktail for enhancing poultry utilization of cocoa pod husk. Sci Res Essay. 4:555-559.

AOAC. 2005. Official methods of analysis. 18 ${ }^{\text {th }}$ Ed. Washington DC (US): The Association of Official Analytical Chemist.

Ditjen Perkebunan. 2011. Luas area dan produksi perkebunan seluruh Indonesia. Jakarta (Indonesia): Direktorat Jendral Perkebunan.

Ginting SP. 2004. Tantangan dan peluang pemanfaatan pakan lokal untuk pengembangan peternakan kambing di Indonesia. Dalam: Strategi Pengembangan Sapi Potong dengan Pendekatan Agribisnis dan Berkelanjutan. Prosiding Lokakarya Nasional Kambing Potong. Yogyakarta, 8-9 Oktober 2004. Bogor (Indonesia): Puslitbangnak. hlm. 61-77.

Ginting SP, Krisnan R. 2006. Pengaruh fermentasi menggunakan beberapa strain trichoderma dan masa inkubasi berbeda terhadap komposisi kimiawi bungkil inti sawit. Dalam: Mathius IW, Sendow I, Nurhayati, Murdiati TB, Thalib A, Beriajaya, Prasetyo LH, Darmono, Wina E, penyunting. Cakrawala Baru IPTEK Menunjang Revitalisasi Peternakan. Prosiding Seminar Nasional Teknologi Peternakan dan Veteriner. Bogor, 5-6 September 2006. Bogor (Indonesia): Puslitbangnak. hlm. 939-944.

Kamara DS, Rachman SD, Gaffar S. 2008. Enzymatic degradation of cellulose from banana stalks for glucose production using cellulolytic activity of Trichoderma viride. In: Proceeding of the International Seminar on Chemistry. p. 692-696.

Mulato S, Widyatomo S. 2003. Teknik budidaya dan pengolahan hasil tanaman kakao. Jember (Indonesia): Pusat Penelitian Kopi dan Kakao Indonesia.

Puastuti W, Yulistiani D, Supriyati. 2008. Ransum berbasis kulit buah kakao diperkaya mineral: Tinjauan pada kecernaan dan fermentasi rumen in vitro. Dalam: Sani Y, Martindah E, Nurhayati, Puastuti W, Sartika T, Parede L, Anggraeni A, Natalia L, penyunting. Inovasi Teknologi Mendukung Pengembangan Agribisnis Peternakan Ramah Lingkungan. Prosiding Seminar Nasional Teknologi Peternakan dan Veteriner. Bogor, 11-12 November 2008. Bogor (Indonesia): Puslitbangnak. hlm. 442-448.

Suparjo, Wiryawan KG, Laconi EB, Mangunwidjaja D. 2009. Perubahan komposisi kimia kulit buah kakao akibat penambahan mangan dan kalsium dalam biokonversi dengan kapang Phanerochaetachrysosporium. Media Peternakan. 32:204-211.

Soleh AZ. 2005. Ilmu statistika pendekatan teoritis dan aplikatif disertai contoh penggunaan SPSS. Bandung (Indonesia): Penerbit Rakayasa Sains.

Steel RGD, Torrie JH. 1993. Prinsip dan prosedur statistika. Jakarta (Indonesia): Gramedia.

Tilley JMA, Terry RA. 1963. A two stage technique for in the in vitro digestion of forage crops. $\mathbf{J}$ Grassland Soc. 18:104.

Toharmat T, Nursasih E, Nazilah R, Hotimah N, Noerzihad TQ, Sigit NA, Retnani Y. 2006. Sifat fisik pakan kaya serat dan pengaruhnya terhadap konsumsi dan kecernaan nutrien ransum kambing. Media Peternakan. 29:146-157.

Utomo R. 2001. Penggunaan jerami padi sebagai pakan basal: Suplementasi sumber energi dan protein terhadap transit partikel pakan, sintesis protein mikrobia, kecernaan dan kinerja sapi potong [Disertasi]. [Yogyakarta (Indonesia)]: Fakultas Peternakan. Universitas Gadjah Mada.

Van Soest PJ, Robertson JB. 1985. Analysis of forages and fibrous foods. AS 613 Manual. Ithaca (USA): Department of Animal Science, Cornell University.

Wahyuni TH, Sembiring I, Sihombing WJ. 2008. Tape kulit buah kakao sebagai pakan kambing Boerka. J Agribisnis Peternakan. 4:65-68.

Yunus M. 1997. Pengaruh umur pemotongan spesies rumput terhadap produksi komposisi kimia, kecernaan in vitro dan in sacco [Skripsi]. [Yogyakarta (Indonesia)]: Universitas Gadjah Mada. 